\title{
TREATMEN BAGI PENGEMIS PADA BALAI REHABILITASI SOSIAL BINA KARYA DAN LARAS YOGYAKARTA
}

\author{
Azmi Mustaqim \\ Prodi Interdisciplinary Islamic Studies Konsentrasi Bimbingan dan Konseling Islam \\ UIN Sunan Kalijaga Yogyakarta \\ mustaqim.azmi10@gmail.com
}

\begin{abstract}
Abstrak
Penelitian ini bertujuan untuk mengetahui treatmen yang diberikan oleh Balai rehabilitasi Sosial Bina Karya dan Laras Yogyakarta kepada pengemis. Penelitian ini menggunakan metodologi kualitatif melalui pendekatan fenomenologis. Subyek penelitian adalah petugas balai rehabilitasi dan dua orang pengemis. Penggalian data dilakukan menggunakan teknik wawancara dan observasi. Analisis data dilakukan dengan mereduksi data, mendisplay data dan menarik kesimpulan. Hasil dari penelitian adalah penyebab seseorang mengemis ada dua, yakni faktor intern dan ekstern. Penyebab intern timbul dari dalam diri sendiri sementara penyebab ekstern dipengaruhi oleh lingkungan individu. Berdasarkan penyebab tersebut didapati karakteristik pengemis adalah tingkat ekonomi rendah (miskin), tingkat pendidikan rendah, tidak memiliki pekerjaan dan meminta-minta, tidak memiliki tempat tinggal, tidak memiliki identitas diri, hidup bebas tanpa aturan, tidak memiliki tujuan hidup yang jelas, dekadensi moral dan sosioemosional rendah, bersifat malas, dan tingkat religius rendah. Oleh karena pemberian satu treatmen yang berdasarkan karakteristik pengemis akan mempengaruhi pemberian treatmen yang lainnya, maka pemberian treatmen dilakukan secara eklektif yang mengkombinasikan beberapa treatmen sesuai kebutuhan.
\end{abstract}

\section{Kata kunci : Treatmen, Pengemis, Balai Rehabilitasi Sosial}

\begin{abstract}
This study aims to determine the treatments provided by Bina Karya and Laras Social Rehabilitation Center Yogyakarta to beggars. This study is using the descriptive qualitative method with the phenomenological approach. The research's subject is Social and rehabilitation center's employ and two beggars. Researcher is taking the data by interview and observation. For data analysis is using data reduce, data display and conclution.The result is, there are two causes of someone being a beggar, internal and external factors. Internal factor comes from individual self and external factor influenced by individual environment. Beggar's characteristic based on the causes of poverty is low economic level, education level, without a job, homeless, without identity, free of lifestyle, without rules, aimless life, moral decadency and socio emotional low, shiftless, and less religious. The treatment provide based on characteristic will influence another treatment. Therefore treatments are given in an eclectic manner that combines several treatments as needed.
\end{abstract}

Keyword: Treatment, a Beggar, Social Rehabilitation Center 


\section{PENDAHULUAN}

Kemiskinan menjadi problem sosial yang hingga saat ini belum bisa dituntaskan. Pengentasan kemiskinan melalui program-program pemerintah belum menunjukan hasil yang signifikan (Muhaimin, 2012: 15). Problem klasik ini utamanya disebabkan oleh kondisi ekonomi yang kurang merata. Kesenjangan ekonomi antara daerah perkotaan dengan pedesaan membuat banyak masyarakat miskin bermigrasi ke kota besar dengan harapan mendapatkan akses pekerjaan yang mudah. Migrasi merupakan perpindahan yang dilakukan oleh individu dari daerah asal ke daerah tujuan dengan maksud untuk mengubah nasib. Namun minimnya skil bekerja dan tingkat pendidikan yang rendah menjadikan sebagian dari mereka sulit mendapatkan pekerjaan hingga akhirnya menimbulkan fenomena kemiskinan kota. Kemiskinan di perkotaan seringkali ditemukan di kota-kota besar, seperti halnya di Yogyakarta. Problem sosial ini belum menunjukan tanda-tanda berkurang atau bahkan hilang. Kemiskinan yang dialami masyarakat pendatang tersebut menyebabkan mereka menjadi masyarakat termarginal secara ekonomi, karena ketidakmampuan bersaing dalam memasuki dunia pekerjaan (Hasyim \& Mudzakkir, 2015: 2). Minimnya keterampilan bekerja berpengaruh terhadap ketidakmampuan memperoleh pekerjaan dan penghasilan, sehingga akan menyebabkan seseorang memintaminta (mengemis) (Abidin, Sangidun \& Budiyono, 2013: 4) atau bahkan mencuri. Akibatnya kemiskinan di perkotaan akan membawa dampak timbulnya fenomena gelandangan dan pengemis.

Data di lapangan menunjukan gelandangan dan pengemis di kota Yogyakarta pada tahun 2013 terdapat 121 gelandangan dan 221 pengemis. Pada tahun 2014 jumlah gelandangan mengalami penurunan menjadi 83 dan jumlah pengemis 199 orang. Terakhir pada tahun 2015 jumlah gelandangan menjadi 82 dan pengemis mengalami penurunan yakni 170 orang (Dinsos Kota Yogyakarta: 2015). Yogyakarta juga telah mengeluarkan Peraturan Daerah (PERDA) nomor 1 tahun 2014 tentang Penanganan Gelandangan dan Pengemis sebagai salah satu cara untuk menekan angka keberadaan gelandangan dan pengemis. Penurunan jumlah gelandangan dan pengemis di kota Yogyakarta juga tidak terlepas dari peran salah satu balai rehabilitasi yang berada di kota pelajar tersebut. Yakni Balai Rehabilitasi Sosial Bina Karya dan Laras yang merupakan unit pelaksana tugas dari Dinas Sosial dan Ketenagakerjaan Provinsi DIY. Panti sosial mempunyai tugas melaksanakan pelayanan dan rehabilitasi sosial bagi penyandang masalah kesejahteraan sosial agar mampu berperan aktif, berkehidupan dalam masyarakat (Kepmensos: 2003). Dibangunnya tempat-tempat rehabilitasi sosial ialah sebagai sarana untuk memberikan pembinaan moral, ketrampilan bagi pelaku penyandang masalah kesejahteraan sosial.

Balai Rehabilitasi Sosial Bina Karya dan Laras Yogyakarta menerima warga binaan gelandangan dan pengemis serta warga eks psikotik (gangguan jiwa). Dalam memberikan rehabilitasi bagi 
gelandangan dan pengemis, balai rehabilitasi sosial memberikan bimbingan antara lain bimbingan keterampilan, bimbingan agama, bimbingan sosial dan bimbingan fisik. Untuk mengembangkan kemampuan dan potensi yang dimiliki pengemis, balai rehalbilitasi sosial melakukan beberapa treatmen mulai awal warga binaan masuk hingga pada proses pengembalian ke masyarakat. Treatmen tersebut dimulai tepatnya sejak warga pertama kali mengalami penjaringan oleh Satuan Polisi Pamong Praja (SATPOL PP), kemudian didaftarkan pada balai rehabilitasi, menjadi warga binaan dan pada akhirnya dikembalikan kepada masyarakat. Treatmen yang diberikan oleh balai rehabilitasi sosial bina karya dan laras diantaranya berfokus pada psikologis, keterampilan, rohani dan sosial.

Treatmen yang diberikan
bertujuan untuk membantu menyelesaikan masalah warga binaan. Pemberian treatmen juga harus disesuaikan dengan kebutuhan warga binaan. Pemberian treatmen merupakan salah satu unsur penting yang harus ada dalam proses rehabilitasi. Proses ini penting sebab rehabilitasi merupakan sebuah proses pemberian bantuan berupa bekal untuk kehidupan setelah keluar dari balai. Treatmen ini berfungsi sebagai upaya edukatif sekaligus preventif agar pengemis tidak kembali ke jalanan. Dalam penelitian ini penulis tertarik untuk melihat bagaimana proses treatmen di Balai rehabilitasi Sosial Bina Karya dan Laras. Selain itu juga untuk mengetahui karakteristik pengemis dan treatmen yang sesuai berdasarkan karakteristik pengemis.

\section{METODE PENELITIAN}

Penelitian ini menggunakan metodologi kualitatif melalui pendekatan fenomenologis. Dengan pendekatan ini peneliti mencoba melihat fenomena treatmen bagi pengemis di balai rehabilitasi sosial Bina Karya dan Laras Kota Yogyakarta. Subyek penelitian adalah petugas balai rehabilitasi diantaranya bagian Pekerjaan sosial, bagian Rehabilitasi Sosial, Konselor dan Tutor Bimbingan dan Keterampilan, dan juga melibatkan pengemis. Penggalian data dilakukan menggunakan teknik wawancara dan observasi. Analisis data dilakukan dengan mereduksi data, mendisplay data dan menarik kesimpulan.

\section{HASIL DAN PEMBAHASAN}

\section{Identifikasi Penyebab Individu Menjadi Pengemis}

Kehidupan di dunia menuntut seseorang untuk berjuang mempertahankan eksistensinya. Kerasnya kehidupan dunia menjadi tantangan yang harus dilalui oleh manusia yang ingin mendapatkan kebahagiaan. Kebutuhan manusia semakin hari semakin meningkat, memerlukan berbagai upaya untuk mencukupi kebutuhan tersebut. Ketidakmampuan sesorang untuk mencukupi kebutuhan hidupnya (kebutuhan pokok: sandang, pangan, papan) menjadi penyebab kemiskinan. Kondisi kemiskinan akan memaksa seseorang untuk mengambil jalan pintas, antara lain adalah dengan mengemis, meminta-minta belas kasihan orang lain. Kemiskinan individu (Oktaviana, Zukhri \& Meitriana: 2014), menyebabkan 
seseorang tidak mampu memenuhi kebutuhan dasar minimal dan menjangkau pelayanan umum, sehingga tidak dapat mengembangkan kehidupan pribadi maupun keluarga secara layak (Tajuddin, 1993: 114).

Menurut Hartono dan Arnicun, faktor yang menyebabkan timbulnya kemiskinan yang menjadikan seseorang mengemis ialah pendidikan yang rendah, malas bekerja, keterbatasan sumber alam, keterbatasan lapangan pekerjaan, keterbatasan modal dan beban keluarga (Hartono \& Arnicun, 2001: 329). Sedangkan Tyas dan Novianti dalam penelitiannya menemukan penyebab permasalahan seseorang menjadi gelandangan dan pengemis adalah masalah ekonomi, pendidikan, sosial budaya, lingkungan, hukum dan kewarganegaraan dan terakhir mental yang kurang sehat. Ia menambahkan sikap malas menjadi problem yang berkaitan dengan mental yang tidak sehat (Tyas \& Noviyanti, 2016: 30-40). Faktor ekonomi yang tidak merata meyebabkan jurang pemisah antara si kaya dan si miskin di kota-kota besar makin melebar (Zafitaningsih, Wibhawa \& Rachim, tt: 9). Faktor usia, misalnya usia lanjut turut andil mengambil posisi sebagai salah satu penyebab seseorang menjadi pengemis. Kondisi tubuh seseorang juga bisa dimanfaatkan, misalnya cacat tubuh, keadaan ini digunakan sebagai alibi dan dimanfaatkan oleh oknum pengemis untuk meminta belas kasihan kepada orang lain (Ahmad, 2010: 15).

Dalam konteks lain, misalnya pengemis di area makam keramat yang dikunjungi peziarah, menurut
Hasim dan Mudzakkir adanya pengemis terjadi karena migrasi warga dari desa ke kota, rendahnya pendidikan, pengaruh sosial dan budaya, ekonomi dan keluarga. Pengaruh sosial dan budaya misalnya, jika seseorang hidup pada lingkungan yang memiliki etos kerja tinggi, maka kemungkinan besar individu tersebut akan terpacu dan meniru apa yang dilakukan oleh lingkungan sosial dan budayanya. Kemudian pengaruh keluarga, ialah dengan adanya model turun temurun yang diwariskan oleh orang tua pengemis kepada anakanaknya (Hasyim \& Mudzakkir, 2015: 1-7).

Ada dua faktor yang menyebabkan seseorang menjadi pengemis, yakni faktor intern dan ekstern. Penyebab intern adalah latarbelakang yang timbul dari diri seseorang tersebut, misalnya masalah rendahnya pendidikan, rendahnya keterampilan, sikap mental, keadaan fisik (cacat tubuh), usia lanjut dan rendahnya kemampuan ekonomi. Sedangkan latarbelakang eksternal adalah pengaruh luar diri yang menyebabkan seseorang menjadi pengemis, misalnya kondisi lapangan pekerjaan yang minim, terbatasnya akses informasi, daya dukung lingkungan, dan keluarga (pengemis warisan).

Penulis menyimpulkan Faktor utama seseorang menjadi pengemis adalah kemiskinan. Kemiskinan ini disebabkan oleh tidak meratanya pembangunan ekonomi, yang dalam konteks ini adalah banyaknya masyarakat yang bermigrasi ke kota besar tanpa memiliki keterampilan bekerja. Selain itu tingkat pendidikan yang rendah, dan beban kebutuhan 
keluarga meningkat. Kemudian mental dan psikologis juga turut mempengaruhi seseorang untuk mengemis. Ditambah lagi seorang berusia lanjut yang tidak hidup sendiri menjadikan seseorang harus mengemis. Terakhir, keluarga yang memaksa anaknya mengemis menjadikan seseorang menjadi pengemis.

\section{Karakteristik Pengemis}

Melihat dari berbagai latar belakang seseorang menjadi pengemis, penulis mencoba mengklasifikasikan dari segi karakteristik bawaan pengemis. Pengklasifisaian berguna untuk mengassesmen pengemis sehingga membantu dalam pemberian treatmen. Efektifitas dan efisiensi dalam pemberian treatmen perlu diperhatikan mengingat waktu rehabilitasi hanya 1 tahun. Maka proses pemberian treatmen harus benar-benar diupayakan secara maksimal dan efisien. Selain itu memahami karakteristik pengemis juga memudahkan pekerja sosial dalam mengembangkanan bakat, potensi yang dimiliki, serta memberi kemudahan dalam setiap proses pelatihan. Karakteristik pengemis yang dimaksud antara lain:

\section{Tingkat Ekomoni Rendah}

Karakter umum yang dimiliki pengemis adalah memiliki kondisi ekonomi tidak mampu atau dalam bahasa sosial adalah "individu rentan miskin". Sebagian besar dari mereka tidak memiliki penghasilan tetap dan tidak memiliki tempat tinggal yang layak. Mereka tidak mampu mencukupi kebutuhan primer (sandang, pangan, papan). Akhirnya mereka mengemis di jalan-jalan, kawasan perumahan, pertokoan atau tempat-tempat umum lainnya.

\section{Tingkat Pendidikan Rendah}

Mayoritas penghuni balai rehabilitasi adalah putus sekolah. Namun sebagian lain tidak pernah mengenyam pendidikan. Bagi mereka yang bersekolah, mayoritas dari mereka tidak menamatkan pendidikan pada tingkat dasar. Alasan mereka pada umumnya adalah ketiadaan biaya, sehingga orang tua mereka dulu tidak mampu mencukupinya. Mereka mengemis berawal dari inisiatif untuk membantu perekonomian keluarga dan terpaksa meninggalkan bangku sekolah.

\section{Tidak Memiliki Keterampilan Bekerja Dan Meminta-Minta}

Banyak pengemis yang ditemui adalah tidak memiliki keterampilan kerja dan meminta-minta. Mereka memilih mengemis untuk mencukupi kebutuhan hidup karena tidak memiliki keterampilan kerja. Meminta-minta merupakan salah satu strategi pengemis untuk memenuhi kebutuhan hidupnya. Mereka melakukan aksi dengan berbagai model, seperti dengan pakaian compang-camping, menggendong anak, menyamar sakit, memakai baju koko dengan dalih untuk amal dan sebagainya (Maghfur Ahmad, 2010: 15). Semua modus tersebut dilakukan untuk mengelabuhi dan menciptakan rasa iba dari orang lain.

\section{Tidak Memiliki Tempat Tinggal}

Kebanyakan pengemis memiliki masalah tidak memiliki tempat tinggal, artinya mereka hidup 
menggelandang. Mayoritas dari mereka tidak memiliki tempat tinggal karena merupakan wargapendatang dan tidak memiliki tujuan yang jelas di tempat baru. Sehingga menjadikan mereka harus tinggal di trotoar, teras pertokoan, ataupun terminal. Beberapa pengemis hidup menggelandang untuk menekan biaya hidup. Bagi mereka yang telah berkeluarga, biasa membawa keluarganya hidup menggelandang dan menjadikan mereka merasa nyaman.

\section{Tidak Memiliki Identitas Diri}

Mayoritas pengemis yang berada di balai rehabilitasi tidak memiliki identitas pribadi atau Kartu Tanda Penduduk (KTP). Seseorang bisa mudah dikenali dirinya salah satunya melalui kartu tanda penduduk sebagai bukti identitas. Banyak dari pengemis berdalih bahwa kartu identitas diri mereka hilang saat terjaring razia. Menurut salah satu pekerja sosial di balai rehabilitasi, mengatakan bahwa pengemis hanya menggunakan dalih hilang saat razia karena sebenarnya mereka tidak memiliki. Namun bagi mereka yang sebelumnya memiliki kartu identitas, cenderung sengaja membuang kartu tersebut supaya tidak dikenali, namun ada juga yang sejak kecil tidak memiliki identitas diri.

\section{Hidup Bebas Tanpa Aturan}

Tanpa memiliki identitas diri menjadikan pengemis hidup bebas atau liar, lepas dari norma kehidupan masyarakat pada umumnya. Hidup menggelandang di jalanan menjadikan mereka tidak mau mentaati peraturan ataupun norma. Hidup bebas juga terjadi pada kehidupan pribadi mereka, bergontaganti pasangan, melakukan seks bebas sudah menjadi sesuatu yang wajar dikalangan pengemis. Namun ada juga diantara mereka yang memiliki kesetiaan terhadap pasangan, meskipun tidak ada ikatan pernikahan hingga mereka memiliki anak.

\section{Tidak Memiliki Tujuan Hidup}

Secara umum warga binaan di balai rehabilitasi sosial bina karya dan laras tidak memiliki tujuan hidup yang jelas. Tujuan mereka mengemis adalah mencukupi kebutuhan hari ini saja, berapapun hasil yang mereka dapatkan hari itu, seketika itu juga akan dihabiskan. Mereka tidak memiliki inisiatif untuk menyisihkan uang. Dan ketika uang mereka habis, mereka kembali mengemis. Karakteristik ini nampak pada beberapa warga yang telah keluar dari balai rehabilitasi. Ketika mengikuti program transmigrasi dan diberi modal dana, mereka menjual tanah dan kembali dari lokasi transmigrasi. Uang hasil penjualan digunakan untuk keperluan hidup mereka, ketika uang tersebut habis, mereka kembali mengemis.

\section{Sosio Emosional Rendah Dan Dekadensi Mental}

Mental sosial yang dimiliki oleh gelandangan dan pengemis ini sangat rendah, terbukti mereka dengan santai dan biasa melakukan tindakan mengemis. Permasalahan yang banyak dijumpai adalah rendahnya mental pengemis. Mental pengemis telah dianggap cacat. Hal ini merujuk pada tindakannya yang selalu mengulangi mengemis meskipun mereka telah keluar masuk balai 
rehabilitasi. Diakui oleh pekerja sosial di balai rehabilitasi, bahwa masalah mental inilah yang menjadi problem pengubahan pola pikir dan perilaku yang cukup berat.

\section{Memiliki Sifat Pemalas}

Kemalasan merupakan karakteristik pengemis, mereka malas untuk bekerja keras. Mereka hanya berfikir dengan meminta-minta akan menghasilkan uang yang banyak tanpa bekerja mengeluarkan keringat. Keyakinan ini yang dipegangi oleh mereka sehingga menjadikan pribadi pengemis semakin malas. Anggapan adalah bahwa pekerjaan mengemis sangat mudah dan lebih menjanjikan banyak uang.

\section{Tingkat Religius Rendah}

Banyak pengemis yang didapati di balai Rehabilitasi Sosial Bina Karya dan Laras adalah penganut agama, baik itu Islam maupun Kristen. Namun dari mereka hanya segelintir saja yang taat beribadah, sementara yang lain tidak mempedulikan. Mereka menganggap agama hanya formalitas saja dan yang lebih penting bagi mereka adalah materi, "uang". Memang sejak dini nilai-nilai agama tidak ditanamkan dalam keluarga karena sibuk mencari nafkah. Meskipun ada beberapa pengemis yang menggunakan doadoa untuk mendoakan orang yang diminta uangnya, namun mereka melakukan itu sebagai modus atau trik merayu orang agar memberinya uang (Maghfur Ahmad: 2010: 6-7).

\section{Mekanisme Pembinaan Di Balai Rehabilitasi}

Identifikasi karakteristik pengemis yang telah dipaparkan di atas, digunakan sebagai landasan untuk memberikan bimbingan. Mekanisme pembinaan yang dilakukan oleh petugas balai rehabilitasi adalah berurutan sebagai berikut, identifikasi dan seleksi, pemahaman dan pengungkapan masalah, orientasi, assesmen dan perumusan atau penentuan program, pelaksanaan bimbingan dan rehabilitasi, tahap resosialisasi, tahap penyaluran, bimbingan lanjut, bantuan pengembangan usaha atau bimbingan peningkatan keterampilan.

\section{Treatmen Bagi Pengemis}

Pemberian treatmen bagi pengemis adalah proses pemberian bantuan penyelesaian masalah secara kontinyu dan berkesinambungan yang dimaksudkan untuk memberikan bekal di kehidupan bermasyarakat. Proses ini diawali dengan penggalian masalah atau disebut konseling. Konseling merupakan proses pemberian bantuan yang dilakukan melalui wawancara oleh seorang ahli untuk menyelesaikan masalah yang dihadapi konseli (Prayitno \& Erman Amti, 2013: 105). Dalam menyelesaikan permasalahan pengemis, proses konseling digunakan untuk menggali permasalahan yang dimiliki warga binaan, selain itu konseling juga dilakukan untuk menemukan potensi individu. Maka selanjutnya setelah diberikan proses konseling, individu akan diberikan bimbingan, yakni proses pemberian bantuan kepada individu agar memperoleh 
pemahaman dan pengarahan diri, yang diperlukan untuk menyesuaikan dirinya dengan lingkungan sehingga dapat mengembangkan potensi diri dengan optimal (Rohmah, 2011: 13).

Tahap konseling dilakukan pada sesi awal pengemis menjadi warga binaan di balai rahabilitasi. Melalui konseling diharapkan individu menyadari terhadap dirinya dan individu memiliki kekuatan untuk keluar dari masalah (Abdul Hayat, 2016: 7).

Pemberian treatmen dilakukan oleh balai rehabilitasi berdasarkan hasil asesemen. Penggalian informasi, penemuan masalah dan potensi digunakan sebagai dasar dalam pemberian treatmen. Individu diberi perlakuan berbeda dari individu yang lain sebagaimana kebutuhannya. Di bawah ini dijelaskan beberapa upaya balai rehabilitasi dalam memberikan treatmen kepada pengemis berdasarkan karakteristik pribadi pengemis.

\section{Tingkat Ekonomi Rendah}

Untuk membantu menyelesaikan permasalahan ini, balai rehabilitasi sosial melakukan beberapa cara, diantaranya adalah memberikan pelatihan ekonomi. Namun balai rehabilitasi perlu mengidentifikasi pengemis terlebih dahulu. Selanjutnya setelah identifikasi ini dilakukan, ialah memberikan pelatihan berwirausaha, misalnya dengan melatih mereka bekerja mandiri melalui program-program keterampilan yang disediakan balai. Pelatihan ini tidak hanya pada saat tahap rehabilitasi, melainkan juga saat pengemis telah dilepas. Pada tahap pelepasan, balai rehabilitasi memberikan bekal pelatihan yang dipersiapkan untuk menguatkan pelatihan yang telah didapatkan sebelumnya, yakni melalui program persiapan dan pelatihan kerja atau magang. Selain itu mereka juga diberikan pelatihan kebutuhan dasar, yakni bagaimana memanajemen penghasilan, mengatur kebutuhan keluarga dan lain sebagainya.

\section{Tidak Memiliki Pekerjaan}

Salah satu upaya yang dilakukan balai rehabilitasi adalah membina seseorang untuk siap bekerja. Yakni dengan program keterampilan las, pertukangan, perkayuan, pertanian, tata boga, kerajinan tangan. Dengan memberikan bekal pelatihan yang aplikatif dalam arti bisa dilakukan segera, diharapkan pengemis memiliki kesadaran dan mau untuk berusaha mandiri. Warga binaan yang dilepas didampingi untuk mendapatkan pekerjaan, diantaranya adalah dengan magang ke beberapa perusahaan serta tempat-tempat usaha rumah tangga. Balai rehabilitasi menggunakan jejaring kerja yang dimilikinya untuk menyalurkan warga binaan. Selain memberi kesempatan untuk magang dan bekerja mandiri, balai rehabilitasi juga bekerjasama dengan pemerintahan untuk mengikutsertakan warga binaan dalam program transmigrasi. Melalui program transmigrasi, balai rehabilitasi berharap mantan warga binaan bisa bekerja sebagaimana mestinya di lokasi transmigrasi. 


\section{Pendidikan Rendah}

Untuk menjembatani permasalahan ini, program edukasi juga disediakan di balai rehabilitasi. Dengan memberikan kelas-kelas edukasi, diantaranya kelas agama, kelas bela Negara, kelas kedisiplinan dan kelas sosial. Namun banyaknya warga binaan yang telah memasuki masa dewasa, banyak diantara mereka enggan mengikuti program ini. beberapa diantara mereka hanya mengikuti program-program kegiatan yang sifatnya praktik yakni keterampilan-keterampilan yang telah tersedia.

\section{Tidak Memiliki Tempat Tinggal}

Upaya yang dilakukan balai rehabilitasi dalam hal ini salah satunya adalah mengikutkan warga binaan pada program transmigrasi. Diharapkan dengan program transmigrasi, mantan warga binaan akan memiliki tempat tinggal yang layak dan juga mampu bekerja secara mandiri. Pilihan lain yang disediakan oleh balai adalah, menampung mereka di balai rehabilitasi sepanjang kapasitas memenuhi. Penampungan ini sifatnya hanya sementara sampai warga binaan secara sukarela meninggalkan balai. Pilihan ini terkadang menjadi problem tersendiri bagi balai rehabilitasi. Dan problem ini belum bisa dicarikan solusi yang tepat. Disisi lain membiarkan mereka kembali hidup dijalanan sama dengan menyuburkan gelandangan, namun ketika membiarkan mereka selamanya tinggal di balai juga menyalahi aturan.

\section{Tidak Memiliki Identitas Diri}

Salah satu upaya untuk menjembatani permasalahan ini adalah pihak balai bekerja sama dengan pihak terkait, kelurahan, kecamatan dan dukcapil sepakat membuatkan identitas warga baru bagi warga binaan. Warga binaan diberikan identitas sebagai warga Negara yang sah dan dimasukan menjadi warga kelurahan Sidomulyo. Identitas baru ini meliputi pembuatan Kartu Keluarga (KK) dan juga Kartu Tanda Penduduk (KTP). Ini merupakan salah satu alternatif terkait permasalahan identitas jika warga binaan kesulitan dalam mengurus identitas diri di tempat asalnya.

\section{Hidup Bebas Tanpa Aturan}

Pembinaan yang dilakukan oleh balai dalam hal ini adalah pembinaan kedisiplinan, pemahaman tentang wawasan kebangsaan dan pelatihan etika. Pembinaan kedisiplinan dan wawasan kebangsaan melibatkan anggota TNI dan juga Polri. Diharapkan setelah mereka keluar dari balai rehabilitasi, mereka menjadi warga yang taat pada aturan hukum amupun nilai-nilai etika yang dianut masyarakat umum.

\section{Tidak Memiliki Tujuan Hidup}

Dalam menanggapi permasalahan ini pihak balai memberikan pelatihan life skill kepada warga binaan. Memberikan pemahaman kepada mereka bagaimana mengatur kehidupan, mempersiapkan kehidupan untuk 
masa depan. Misalnya dalam hubungan antar warga, ketika mendapati warga yang memiliki pasangan, balai memfasilitasi pernikahan yang sah jika warga binaan bersedia untuk berumah tangga. Cara ini sering ditwarkan kepada warga binaan yang memiliki kesadaran untuk berumah tangga.

\section{Kondisi Sosio Emosional Rendah dan Dekadensi Mental}

Terkait rendahnya sosioemosional warga binaan, balai rehabilitsi memberikan pelayanan konseling baik individu maupun kelompok. Konseling kelompok biasanya dilakukan di awal masa penerimaan warga binaan. Selain itu konseling pribadi juga dilakukan secara berkesinambungan selama masa rehabilitasi. Permasalahan yang ditangani dalam proses konseling biasanya menyangkut permasalahan pribadi, hubungan dengan sesama warga dan lain sebagainya. Terkadang dalam proses konseling juga dilakukan proses evaluasi dalam arti dilakukan dalam rangka melihat keefektifan individu dalam mengikuti pelatihan keterampilan. Jika didapati individu yang jarang hadir mengikuti pelatihan, maka balai rehabilitasi melalui konselor akan memanggil warga binaan yang bersangkutan dan menyelesaikan alasan keengganan mengikuti program pelatihan.

\section{Kemalasan}

Dalam menyelesaikan problem ini balai rehabilitasi memberikan dorongan kepada warga binaan untuk selalu dan senantiasa mengikuti program-program balai. Dengan seperti ini sedikit demi sedikit mereka akan tergerak untuk menghilangkan rasa malas. Selain itu adanya program pelatihan keterampilan juga merupakan salah satu bentuk pembinaan untuk mengurangi kemalasan.

\section{Tingkat Religius Rendah}

Balai rehabilitasi memberikan pembinaan rohani baik bagi warga binaan yang beragama Islam maupun Kristen. Bagi mereka yang beragama Islam mereka diberikan pembinaan dalam bentuk teori dan praktik-praktik ibadah. Mulai dari dasar-dasar pengenalan agama hingga ritual-ritual agama. Instruktur agama yang ditunjuk memberikan pelatihan-pelatihan ibadah yang sangat mendasar, salah satunya dengan melakukan pelatihan sholat. Pemberian materi-materi dasar ini dilakukan dengan alasan warga binaan merupakan orang yang sangat awam dengan agama, latar belakang mereka yang asing terhadap agama memerlukan pendekatan yang pelan pelan dan dimuali dari sesuatu yang sederhana dan mendasar.

Permasalahan pengemis adalah permasalahan dasar atau primer dari kehidupan manusia yang ketika hal itu tidak segera diselesaikan akan mempengaruhi kehidupan mereka yang lainnya. Masing-masing karakter akan membawa dampak bagi karakter yang lainnya, oleh karena itu penting kiranya dalam memberikan pembinaan antara satu dengan yang lain harus saling berkaitan. Pemberian 
treatmen dan pembinaan yang dilakukan di balai rehabilitasi sosial bina karya dan laras dilakukan secara eklektif. Yakni berusaha memberikan semua kebutuhan dasar bagi mereka sebagai bekal membangun kehidupan dengan mengkombinasikan teratmen sesuai kebutuhan.

\section{KESIMPULAN}

Berdasarkan pemaparan yang dimaksudkan diatas, maka dapat diambil kesimpulan bahwa penyebab seseorang mengemis dikelompokan menjadi dua hal, yakni penyebab intern dan ekstern. Penyebab intern timbul dari dalam diri pengemis sendiri semantara penyebab ekstern dipengaruhi oleh lingkungan pengemis. Berdasarkan penyebab tersebut didapati karakteristik pengemis adalah tingkat ekonomi rendah (miskin), tingkat pendidikan rendah, tidak memiliki pekerjaan dan meminta-minta, tidak memiliki tempat tinggal, tidak memiliki identitas diri, hidup bebas tanpa aturan, tidak memiliki tujuan hidup yang jelas, dekadensi moral dan sosioemosional rendah, bersifat malas, dan tingkat religius rendah. Oleh karena pemberian satu treatmen yang berdasarkan karakteristik pengemis akan mempengaruhi pemberian treatmen yang lainnya, maka pemberian treatmen dilakukan secara eklektif yang mengkombinasikan beberapa treatmen sesuai kebutuhan. Namun yang paling utama dan perlu menjadi penekanan dalam pemberian treatmen adalah mengubah pandangan mental pengemis.

\section{DAFTAR PUSTAKA}

A.M, Yuki Deli. (2014). "Efektifitas

Pembinaan dan Pelatihan

Gelandangan dan Pengemis

Oleh Dinas Sosial dan

Pemakaman Kota Pekanbaru".

Jom Fisip. Vol. 2. No. 1. 1-15.

Abidin, Zainal. Sangidun \&

Budiyono, A. (2013)

"Penanganan Problematika

Pengemis, Gelandangan dan

Orang Terlantar (PGOT)

Melalui Bimbingan dan

Konseling Islami di Balai

Rehabilitasi Sosial Martani

Cilacap". Jurnal Komunika

Jurusan Dakwah STAIN

Purwokerto. Vol. 7. No. 2. 1-

22.

Ahmad, Maghfur. (2010). "Strategi

Kelangsungan Hidup

Gelandangan-Pengemis

(Gepeng)", Jurnal Penelitia., Vol. 7. No. 2. 1-16.

Anggraini, Tyas M. dan Dewi, Noviyanti K. (2016).

Identifikasi permasalahan Gelandangan dan Pengemis di UPT Rehabilitasi Sosila Gelandangan dan Pengemis", INQUIRY Jurnal Ilmiah dan Psikologi. Vol. 7. No. 1. 3040.

Asy'ari, Hasyim \& Mudzakkir, Moh. (2015). "Pengemis dan Makam: Fenomena Pengemis di Makam Sunan Giri Kabupaten Gresik". Jurnal Paradigma. Vol. 3. No. 2. 1-7.

Dokumentasi Dinas Sosial Yogyakarta tahun 2015.

Effendi, Tadjuddin Noer. (1993). Sumber Daya Manusia 
Peluang Kerja Dan Kemiskinan. Yogyakarta: Tiara Wacana.

Hartono dan Aziz, Arnicun. (2001). Ilmu Sosial Dasar. Jakarta: Bumi Aksara.

Hayat, Abdul. Konsep Konseling berdasarkan ayat-ayat Al Quran. (2016). Yogyakarta: LKIS.

Keputusan Menteri sosial Republik Indonesia, (2003). tentang Organisasi dan Tata Kerja Panti Sosial di Lingkungan Departemen Sosial. Jakarta.

Muhaimin,. (2012). “Analisis Hukum Terhadap Efektifitas Pelaksanaan Kebijakan Pemerintah Dalam Pengentasan Kemiskinan dan Model Penyelesaiannya". Jurnal Dinamika Hukum. Vol. 12. No. 1. 15-26.
Oktaviana, Maulida. Zukhri, Anjuman. \& Meitriana, Made Ary. (2014). "Pengemis dan Upaya Penanggulangannya (Studi Kasus Di Desa Rarang Tengah Kecamatan Terara Kabupaten LombokTimur), Jur Penddikan Ekonomi. Vol. 4 No. 1.

Prayitno \& Amti, Erman. DasarDasar Bimbingan Dan Konseling. (2013). Jakarta: Rineka Cipta.

Rohmah, Umi. (2011). Pengantar Bimbingan dan Konseling. Ponorogo: STAIN Po Press.

Zefitaningsih, Betha D. Wibhawa, Budhi. \& Rachim, Hadiyanto A. (Tt.) " Penanggulangan Gelandangan dan Pengemis Oleh Panti Sosial Bina Karya Pangudi Luhur", Prosiding KS: Riset dan PKM. Vol. 3 No. 